\title{
Business Administration and Management
}

\section{The Odyssey of the Cameroonian Nation: Historical Trajectory of "Living Together" and its Political Exploitation Margins}

\author{
Aristide Menguele Menyengue* \\ Department of Political Science, University of Douala, Douala, Cameroon
}

"Corresponding author: Aristide Menguele Menyengue, Department of Political Science, University of Douala, Douala, Cameroon. Email: m.aristidemichel@yahoo.com

Citation: Menyengue AM (2018) The Odyssey of the Cameroonian Nation's Historical Trajectory "Living Together" and its Political Exploitation Margins. Arch Bus Adm Manag: ABAM-114. DOI: 10.29011/ABAM-114. 100014.

Received Date: 10 August, 2018; Accepted Date: 05 October, 2018; Published Date: 15 October, 2018

\section{Introduction}

Whether considered as an abstract concept, that is to say "a soul, a spiritual principle"[1] and then as "a more or less institutional historical community occupying a given territory, or his homeland and sharing a language and a distinct culture"[2], The nation is a permanent construction. According to Lavroff, "nationbuilding has two aspects: the establishment of political institutions and the creation of a mentality of belonging and participation in the political system"[3]. But these jacobinists forms of nationbuilding neglect the multicultural characteristics of plural societies and their cosmopolitan components as it is the case in Cameroon. Here, "Cameroon's conception of the nation"[4] does not imply a systematic repudiation of particularities. This duality is reinforced by homological conception that equates "nation", "people" and "culture"[5].

Be it hasty, the evaluation of the nation-building policies in Cameroon leads to integrate "the long term" and "the short term", "the synchrony and" the diachrony". Although Braudel notes that "the political history is not necessarily "Event" or "doomed to be"[6], It is difficult understand the historicity of the construction of "living together" by neglecting its "evenemential aspects". Moreover, in his observations on "retour de l'évènement" Paul Ricoeur notes:

that the non-event-story brought to light, are structures and unstable circumstances that leave room for the unexpected, the quota and that, in this sense, call the event as the third term of the triad structure conditions, events[7].

It would therefore be advisable to incorporate «la longue durée» and «events», «le stable» and «le variable» pretend to account for the mechanisms enlisted to establish this essential communalization [8]. Indeed, if there is an insatiable policy of promoting national feeling (1) it remains constant that we cannot heuristically analyse this nation building process by ignoring the «evenemential» expression of the «living together» in Cameroon (2).

\section{Insatiable materialization of national feeling in Cameroon}

Ethno centered and socio-centered perceptions which consider the nation building as an hegemonic alliance between dominant ethnic groups appear to be one of the severe critics of political integration in Cameroon[10]. The economy of the "voice option"[9] argues that there is a process of "mutual assimilation"[11] in state mechanisms for the promotion of "living together" and national integration which have been instrumentalized in order to legitimate authoritarianism. The conference Foumban can be convoqued to illustrate it (A).

\section{The nation building process and the political use of the dialogue : the case of Foumban Conference}

Historically, the aim of the nation building process initiate by Cameroon's political authorities was to reach the level where "the citizens would first identify themselves as Cameroonian before presenting themselves as Bamileke, Ewondo, Fulani, Bassa, Bulu, Douala, Bakweri Baya or Maka"[12]. In this historical context where allegiance to the primary group of solidarity and, alternatively, to the linguistic community seemed stronger than allegiance to the nation, the aim was to "transform Cameroon into a state [since] the nation will follow"[13]. The different conceptions of the nation did not facilitate the necessary consensus on an authentic nation which can integrate and transcend all kind of cleavages and particularities specific to the ethnic groups established in Cameroon. Thus, the first interpretation of national unity suggest that "unity referred first to the merger of the two populations of "Cameroon", namely the "French Cameroon" and "Anglophone Cameroon"[14]. But 


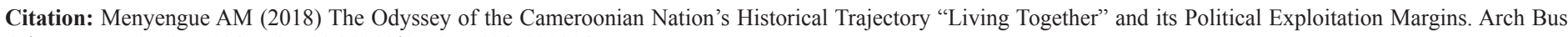
Adm Manag: ABAM-114. DOI: 10.29011/ABAM-114. 100014.

the Francophone Cameroon's independence on January, 1rst, 1960 gives a new impetus and an alternative meaning to the process of national integration. This is one of the major induced effect of the birth's declaration of a nation whose president Ahidjo will proclaim later in these words : "a nation is born! Its appearence was painful as the release of all the great nations "[15]. This birth attestation of the nation appears to be a personal revendication of an outcome of a collective will for purposes of political domination [16]. The benefits of consultation and consensus around the "living together" profite to all the supporters of the presidentialization the political regime in Cameroon.

In fact, this birth's declaration of a Cameroon's nation was accompanied by a pro domo revendication of the legitimate paternity of the nation. Thus, the "founding father" legitimate messianic position that has been historically constitutionalized since the relevant provisions of the constitution have consistently make the President of the Republic the "elected of the entire nation", the one who "embodies national unity", and the one who "defines the policy of the nation" and "the guarantor of national independence"[17]. In short, "he embodies the nation because he is carrying a message"'[18]. But the outcome of the vertues of dialogue in the nation building process proved fraudulent means in the process of national integration in the light of events related to the Foumban conference. Undoubtedly, the event from June 1, 1961, called "Day of Mourning" has been decisive in the notice of the foundations of Foumban. In fact, the aim of the "national mourning day" was to commemorate the incorporation of more than 800,000 people outside the borders "of the motherland". The Foumban conference was also an instrument of territorial reconfiguration which aim was to (re)define the national territory and the nature of the state. It had led to leave the confederal system which was "very expensive" and adopt a federal state organization best able to promote national identity. The "golden age" of this dynamic will be achieved on May 20th, 1972 with the creation of the United Republic of Cameroon following a referendum. It was during the speech "About the third five-year plan" on August 12th, 1971, that President Ahmadou Ahidjo evoked some elements of justification of this evolution: it is "the continued consolidation national the unity" which should support "a nation in which the need for unity increases more and more " and the cost of increasingly high operation of the federal state [19].

The advent of the unified state reflects a dynamic of national construction that is betting on a particular type of form of state considered more suitable for the foundation and consolidation of the nation. From Confederation to the unitary state passing by the federation, it was a question of finding the form of state more compatible with the ideal of national unity. This historical trajectory shows that "state-building and nation-building are both works of art resulting from a conscious effort of the leaders"[20].
But, in practice, the enforcement mechanisms of the unitary state and the nation contributed also to achieve some political rationalities which was both individuals and collectives. Foumban Conference appears to have raised the technic of "capitalization of the symbolic resource of consultation"[21]. According to Louis Marie M. Nkoum-Me-Tseny, "Foumban represents a positioning failure of the Federated State of Cameroun Occidental (CAMOC) who will be born in the Cameroon-federation"'[22]. The foundation of Foumban offered a "window of opportunity" in realization of the noble ambition that was assigned to founding fathers of Cameroon as a State : building a Cameroonian identity beyond the divisions of all particular linguistic orders. The tangle of political opportunities skewed the first intention and the initial plan. Logically, Mr. Louis Marie Nkoum-Me-Tseny concludes that personal causes have prevailed over the collective and distorted them. The author's statement acquires more relevance when its highlights:

all English partners - except Dr. Endeley, and for other reasons - were rewarded with political trophies bringing mainly to government positions. For example, the head of delegation Mr John Ngu Foncha will cumulatively Vice President of the delegation of Cameroon and Prime Minister of West Cameroon while his companion Salomon Tandeng Muna will turn Minister of State, Vice President the Federal Republic of Cameroon concurrently with his duties as Prime Minister of West Cameroon [23].

Although he was betrayed by the voluntary omission of the rotation requirement of presidential power between French and English for better sit national unity, "the spirit of Foumban" likewise influences the creation of a unified national party [24]. The episode of the unified party in "the United republic" (19621972) is from this standpoint the logical continuation of both a bricolage and strategic vision policy.

The advent of the Cameroonian Union (UC) September $1^{\text {st }}$, 1966 is an "(un)constitutional political coup" which was imposed by "ignoring the multipartism system emphasized then in Article 3 of the Constitution" which provided that "political parties and groups exercise of suffrage. They form and operate freely within the framework set by law and regulations". The party becomes a powerful factor of national unity under the tutelary figure of the "father of the nation". In addition, the Cameroon National Union $(\mathrm{CNU})$ as a tool for national integration born of the agreement between the three dominant political parties, primarily the Kamerun National Democratic Party (KNDP), the Cameroon People's National Convention (NOC C) - for West Cameroon - Cameroon and Union-for-eastern Cameroon is especially pose as an institution of legitimation of an "hegemonic project" in the name of national unity. As proof, the Cameroon National Union will be the first structure against which political allegiance will be appreciated; hence the emergence of the register of stigmatizing "maquis", "parti 


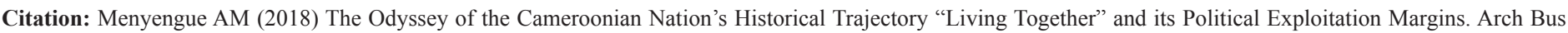
Adm Manag: ABAM-114. DOI: 10.29011/ABAM-114. 100014.

clandestin" or "terrorist." The nation's enforcement mechanisms also operate by the political exploitation of the law (B).

\section{The political use of the law in the construction of "live together"}

The rythm and the frequence of Cameroon's constitutionalism is an indicator of continuous solicitation of legislation by the politics. This constant solicitation of the constitutionalism can be proved through the indication of the number of Republics experimented. A kind of "normative Darwinism" and "legal evolutionism" [25] accompanies the process of nation building. As far as nation building is concern, the Cameroon's constitution(alism) takes the appearance of a flexible one taken into account the frequency and the rate of its handling. From the federal to unitary State the "making of law" was used to transcribe the legal foundation of political will of a nation. Almost four republics in 50 years, even if we sometimes consider the Fourth Republic as "the Third Republic bis or caesarean delivery of the Fourth Republic shameful and hypocritical" [26]. Whatever the case, the dynamics of the Cameroon's constitutionalism seems to be orientated de jure toward "reactivating the sense of belonging to the national community" [27]. To do this, all the mutations Cameroun's constitutionnalism (constitutional amendment or new constitution) were initiated by the courtesan technical "support motion," "call of the people," "Call of the nation." This technique allows to present the initiative to the constitutional change as belonging to this body are atypical as constitution-maker or constituent body : "the living forces of the nation."

The category of "living forces of the nation" is difficult to describe in terms of constitutional theory. Is it an original constituent body or organ derived constituent? The ambiguity about the exact nature of this legal-political category informs about the nature of the product which is officially promoter. The constitutional challenge of national integration has the angle displays symbolic of the consensual approach. On $10^{\text {th }}$, May 1972, for example, the speech on the occasion of the referendum campaign on the constitution of the United Republic of Cameroon is part of this logic. In that speech, President Ahmadou Ahidjo said:

That the draft constitution, published today and which I submit to referendum, thus at the heart of a historic movement to the credit of Cameroon, is both, my dear compatriots, ensuring it matches the profound will of the nation its full support and full membership [28].

It is the same case for the information procedure of the Constitutional Law on Nature undecided 18 January 1996. The enterprise begun with the sustained claim demanding the holding Cameroon to a sovereign national conference, institution widespread in sub-saharan Africa at that particular time, the movement leading to the announcement of a "broad discussion" which turns into a sort "baroque" constituent assembly: the tripartite. It is presented as a survival of "the African palaver" where plays a multiplesum power struggle. On the one hand government control of the transition, the other the conquest of "political trophies" at different levels and this also means according to the different (bargaining, clientelism, cooptation and taxation, etc.). The least we can see what that without being subject to manipulation [29].

In this context, "the entrenchment of a pluralistic national identity or released" [30] reflects the balance of power at the heart of the constitutional revision of January $18^{\text {th }}, 1996$ [31]. It proceeds from "the constitutional imagination of the nation" [32]. The proliferation of "ethnic territories" to uneven integrative value introduced new asymmetric identity categories that convey the devoted concepts of "indigenous" and "minorities groups". The legal reception of these concepts led to the production of asymmetric effect of nationality as it has been shown during the "anti bamiléke march" of January 21, 1996 after the municipal elections that consecrated an increasing Bamileke number at the head of the municipal executive in the littoral region. The syncretic political system has long served as a shield to a presidential regime de facto[33]. It was the major issue of the hybrid nature of the Cameroon's political regime qualified as "halfway regime" by President Ahidjo[34]. However, "the prototype of the regime "impure" or "mongrel" is actually" a resurgence of African presidentialism, it is direde "hyper-presidentialism" with one of the major features is the personalization of power" [35]. Practically, the option to presidentialism regime in Cameroon has always imposed by the technique consisting in exaggerating the risk of cosmopolitanism on national cohesion.

The theoretical validation of presidentialism braces itself on the imperative and the need to identify an institution both symbol and embodiment of the nation: The Head of State. He is the one who has the "monopoly of representation of the unity of the state" [36]. In the same vein, the recent constitutional revision of 14 April 2008 that removed the limitation of the presidential mandate justified by the technology of " people call" [37]. This compilation of nearly 180 support motions from 10 regions of Cameroon and all social origins, was conceived in order to legitimate the consensual approach of consolidating a "perpetual government" [38] presented as necessary to the purpose of "living together". So longevity in power becomes an instrument of promotion and consolidation of the nation and of "living together" that avoids the isolationism that can lead the struggle for the conquest and control of presidential power [39]. Hence, the institutionalization the non-limitation of presidential mandate since the first President of the Republic (1960 to 1982 that is 25 years of power) to his successor President Paul Biya who has been in power since 1982 and who has a long experience of 35 years of presidency nowadays (1982-2017). The initiators of the constitutional revision of 14 April 2008 which established the non-limitation of the presidential 


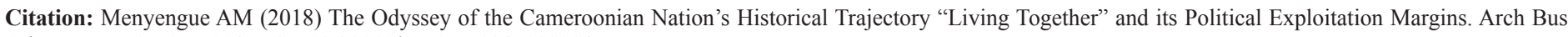
Adm Manag: ABAM-114. DOI: 10.29011/ABAM-114. 100014.

mandate pretended that the consolidation of the nation depended on the continued rule of President Paul Biya because "[he can preserve] the peace, and sustain the grandiose and exciting work of the nation building"[40]. Thus the "perpetual government" and longevity in power are legitimate by "la longue durée" in which the work of the nation building is fulfilled. As the nation still needs "his founding(s) father(s)", it was necessary to constitutionalized the non-limitation of presidential mandates in order to allow the Head of state to continue to build the nation he represents as stated in the fundamental law. The Nation building enterprise mobilizes because it is also an opportunity to realize political transactions. This is particularly noticeable in the political and administrative mechanisms of promoting political integration and nation building.

\section{The promotion of the nation building in administrative structures : the institution of regional balance}

Often described as a form of "normative protection of national unity"[41], the regional balance in the political and administrative structures in Cameroon entertains grievances. This happens because “"

Legislatures have a special symbolic role in representing the citizens of a country. Citizens who would not see represented in the legislatures might feel rejected in the political process and would question its legitimacy[42].

In fact, it appears that "the claim of identity is a prerequisite for any political integration"[43].

In the Cameroonian context, the political integration through the regional balance influences the institutional dynamics in a quasi-deterministic way. In fact, the political and administrative structures draws its legitimacy from regional balance which guaranteed their representativity. The political and administrative building of the nation allegiance declines asymmetric citizen compared to administrative functions quantity and quality. First, because the political and administrative functions do not have the same social value and are scarcely equivalent. Secondly because the eligible functions are subject to seasonal activities in Cameroon where the national assembly or the senate does not work continuously and permanently.

The mechanisms of "geopolitical macro-dosage" and "ethnic microdosage" otherwise known regional balance have a legal basis[44]. This allow state's authorities to implement the international legal instruments on minority rights guaranteed through the technique of positive discrimination: the "affirmative action". This also permit to apply the preambles of successive constitutions proclaiming that the Cameroonian people is "proud of its linguistic and cultural diversity, part of its national identity"[45].
Finally, it comes to the application of Decree No. 010467 / MFP / DC, October 4, 1982 implementing the provisions of Decree No. 82-407 of 7 September 1982 fixing the quotas for places from each administrative region competition and duDécret No. 2000/287 of 12 October 2000 amending and supplementing certain provisions of Decree No. 94/199 of 9 October 1994 on the general status of the Public Service of the State of Cameroon. Upon observation, the regional balance is a principle of promoting "living together" which helps to promote the political and administrative representation of ethno-regional groups that established in the national territory in such a way that every Cameroonian citizen can s identify himself in the political and administrative elites who rule the state.

However, the implementation of "regional balance" as an integration tool is not exempted of political instrumentalization. Cameroonians often quarrel the inequitable repartition of position of power in the state between the different ethno-regional groups and its relation to administrative efficiency. It is this balance of power practiced in the politico-administrative function that explains the dynamics of government inflation. The numerical increase in ministerial department in Cameroon remains quite problematic. It is a clientelist legitimacy constraint. Van Den Wall mobilizes this hypothesis to explain the government overcrowding by the constraint to legitimize governments in multiethnic context in the following excerpt [46].

For example, the first government of independent Cameroon formed on May $16^{\text {th }}, 1960$ consisted of 19 members. Currently, the historical dynamics of such a regional balance in the government of December $08^{\text {th }}, 2004$ increases the government staff to the number of forty one ministers (41 ministers precisely). If a "cabinet reshuffle designed under the sign of efficiency" must necessarily be "without considering that in the old parliamentary countries, called political assays"[47], one can argue without questioning the effectiveness of the policy of regional balance because of overcrowded structures it promotes.

The effectiveness of such a heavy structure is problematic because it is assumed that the small-sized structures are far more efficient than large size structures more likely to cacophony, competences disputes, inertia and "plot[48]. "The mirror representation"'[49] as consociationniste mechanism of legitimization of political institutions, national integration and promotion of "living together" can have perverse effects. In practice, the regional balance accumulates at least four variables: the geopolitical micro balance, the regional microdosage [50]The technique called "linguistic lining" and ethno-religious variable. These growths genuine regional balance learn about the variety of places and sites more so identifying that "the identity of the individual is related to collective identities"[51]. The practice of regional balance contribute to sustain national unity; it has to do with the "sociation "[that is to say]" provision of social activity 


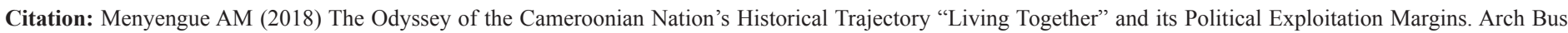
Adm Manag: ABAM-114. DOI: 10.29011/ABAM-114. 100014.

that is based on a compromise of interests rationally motivated or motivated coordination of interests in the same way "[52].

The gap between quality and quantity in the political and administrative levels cooptation of ethnic groups is an indicator of "consociationnalisme" evoked Lijphart[53]. Frustrations are relayed through memoranda criticizing the group access to positions of power and low political and administrative representation[54]. The youth of Kumzi opened letter addressed to Bamiléke children criticizing the National President of the Democratic Rally of the Cameroon People (CPDM) is highly illustrative:

Our parents continue to make policy austria and have the Scribble complex supporting the CPDM [...] Our parents continue to do the donkey! But we young Kumzi we, Children Bamileke did say stop the killing! Enough is enough [...] a Bamileke has never been neither Finance Minister or minister of Industry, nor minister of National Education of territorial administration, armed forces, why?[55].

This is the denunciation of the North-South ethnic hegemonic alliance. The return of democratization imposed an aggiornamento of the regional political and ethno report that might cause effects of "delegitimization of the unitary order"[56] and which often results in inflation of the memoranda produced by ethnic group to claim their integration and condemn their marginalization [57]. Now the political and administrative integration of ethnoregional groups is a stake of the political market and submit therefore to political transaction: this explains the theory of "transactional government"[58] translated through "the politics of affection"[59]. Under this report, as underlined Luc Sindjoun, "the regional balance policy can appear to be cosmetic concealment of ethnocratic nature of a system of political domination"'[60]. His political side that is the institutionalization of government platforms or government coalitions is another tool building national unity whose political stakes go beyond the issue of national integration. Haggling, clientelism but especially phagocytosis are setbacks. That is why the political parties that are compromised in this game phagocytosis pretext to bring the nation institutionally weakened and lost their pride. Territorial balance of opposition parties like the National Union for Democracy and Progress (NUDP), Union of the Populations of Cameroon (UPC), the Democratic Movement for the Defense of the Republic (MDR) [61]. From this point of view, opening government do not exclude the balance of power on the understanding they appear ultimately as instruments continuation of politics by other means, to paraphrase Clausewitz [62]. "National unity as director concept"[63] is a political strategy of domination and hegemonic construction that can also borrow its modes of objectification events (II).

\section{Events in the promotion of "live together"}

The relative impact of national integration policy measures in
Cameroon has intensified decisively the option of seeking potential stimulators of national feeling. Despite the "evenemential" aspect of such measures, mobilized as stimulators of "communalization" and "living together", it is proved that they contribute decisively to the promotion of national feeling. Three types of considerations may be called to demonstrate the importance of the events in the promotion of "living together" in Cameroon. They are : the nation building trough the unifying and mobilizing function of the conflict (A), the playful realization of "living together"(B) and the promotion of national integration by public development policies (C).

\section{"The enemies of the nation" in the materialization of the national feeling}

It is proved that conflicts or hostility has a decisive role in the enunciation of the sense of community allegiance [64]. In Cameroon, the nation building through the mobilization of the unifying function of conflict has been decisive during the conflict against "the terrorists", in the conflict against Nigeria for the control of the Bakassi Peninsula and in the conflict against the Islamist sect Boko Haram, etc. Thus, the Cameroonian emulation in the expression of national allegiance occurs also through the effect of "sociation". The conflict against a common enemy positively stimulates national feeling. Formerly, the common enemy inside the national territory was build around the figure of illegal opposition (UPC) whose looting and massacres were beginning seriously to jeopardize the construction of a common destiny. The lexicon convened to identify the common enemy inside the national territory was very suggestive ("maquisards", "resistance fighters," "terrorists", "enemies of the nation", "apprentis sorciers", etc.). Trough this process, it is the mobilizing effect of nominal identification of the common internal enemy is sought.

The official condemnation of "maquis" practiced by illegal UPC in the years of independence is an example. The historical identification of external enemy thus proceeds from a desire to subsume or transcend more or less rival identities by mobilizing the unifying feature of the conflict. In fact, as Murray Edelman explained, "political leaders [...] often stimulate the zeal of their followers by focusing on external dangers that make forget the unresolved internal problems"[65]. In this perspective, we often called the paradoxical formation of the Cameroonian nation by using the communalizing effect of the conflict between Cameroon and Nigeria concerning the Bakassi Peninsula. According to Zachari Ngniman, the Bakassi conflict gave rise to a pass of exorcism. Domestically, there was evidence that over time it had allowed to constitute a remarkable consensus of opinion in the class and led in the political environment, despite some insatiable criticism from the opposition for a certain period, the great violence that characterized the democratization process in the early 1990 [...]. the great consecration of this consensus, the military and civilian 


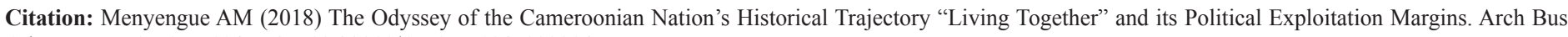
Adm Manag: ABAM-114. DOI: 10.29011/ABAM-114. 100014.

parade on May 20, 1994 marking the 22nd National Day mobilized for the first time the Social Democratic Front activists (SDF) first formation of the extra parliamentary opposition who always had advocates boycott of this event "[66].

The dialectical effect of the conflict has allowed "to individuals and groups who would otherwise have nothing to do together to be brought to cooperate "[67]. In the same vein, the conflict against Islamist sect Boko Haram has helped the maturation of the nation building process which was jeopardized by jihadists. It was followed by a great mobilization in favour of the consolidation of the nation building process. This helped to prove the commitment and solidarity with their northern compatriots and proven through multiple forms support and institutionalization of "l'effort de guerre" by which all Cameroonians proved their solidarity to their northern compatriots [68]. This has helped to produce a particular form of "communilization" trough the unifying effects of conflict community which also applies to other situations of adversity engaging nations as for sports competition. Therefore, it is necessary to analyze the effects of "sportization"[69] in nation building process in order to understand the playful realization of "living together" and national intergration (B).

\section{Playful realization of national affection and "living together"}

The playful realization of national integration is understood more easily when one keeps in mind the socio-political functions of the game [70]. One can be convinced by admitting that "sport shares with other leisure activities that mimic nature, this ability to arouse emotions"[71]. If interstate competitions excite and stimulate the national feeling, it is mainly because sports like the conflict "is a continuation of politics by other means" to quote Clausewitz[72]. In the Cameroonian context, the sports movement political issue, gives pride to football even though it has been said that "in Cameroon, there are no major sports, minor sports or sports reserved" [73]. in Cameroon Football is not just a game. It is eminently political, when considered "living together" that it helps to consolidate. In fact, the national football team of Cameroon "The Indomptables Lions" are a strong symbol of Cameroon's national unity. As it has been emphasized by the President of the Republic Paul Biya, Cameroonians all agree on the fact that when "the Indomitable Lions are engaged in an international competition there is neither Bamileke nor Beti nor English, nor Fulani "but just a unanimous nation. In fact, "football built an imaginary community"[74]. That is why in his address to the nation on $31^{\text {st }}$ December, 2009, President Paul Biya was able to proclaim the existence of a nation based on the mobilizing effects of football. As noted by the President of the Republic, today there is a Cameroonian nation. [The] national unity is not an empty word. The proof is that, when the Indomitable Lions perform in international competitions, which Cameroonian does not feel enormous pride, whatever their place of origin?[75].

But, the realization of the national integration through football in Cameroon is experiencing dysfunctions. These are inherent tendencies of "political capital" that feed the perception that football is a "political instrument"[76]. Although marginal and isolated opinions are testing the unifying factor of the sport and particularly football, this game has greatly contribute to the nation building process by promoting the national pride and feeling. There are several foundations of this approach; among others, the politization of football and quarrels around the management of football in Cameroon. In addition, the conflicting relationship between players of the national football team which often lead to "fan clubs" or ethnic quarrels notably when the squad is defeated. In this perspective, it is advisable to consider that the unifying effect of football is particularly relative. However, its contribution was decisive in politics, particularly in the promotion of "living together".

\section{The realization of national integration through public policy development}

The promotion of local development is another tool in the nation building process which aim is to consolidate national cohesion. As far as ethno-regional groups are concerned, people often feel integrate when one of them (either their son or their daughter, etc. ) is appointed member of the government of the Republic or general manager, etc. They may also exalt the nation because of development projects that are built in their respective regions or localities. There is an abundant literature on motions of support that communities and ethnic groups address systematically to the Head of State when they are benefit from a decree appointing one of their son or daughter, or when a development project is announced or carried out in a locality [77]. This is another way of promoting the "will to live together" by developing local projects all over the nation such as the development of road infrastructure. According to President Ahmadou Ahidjo, " the road is a catalyst for national development and a catalyst of national unity"[78]. Therefore, by dwelling on the development of road infrastructure, it was taken into account the role of road infrastructure not only in the context of the consolidation of the national economy, but also in the sense of building national unity because meeting and mixing of populations allow them to know, to communicate and to intimately share the same ideals in the unity of the same national destiny[79]. It is the aim of the three-year development plan or contingency plan for the development of the Far North[80].

In addition, the institutionalization of the "self-centered development" or "developpement aut-centré" also comes from the will of local promotion of the nation through the policy of redistribution of the national wealth between regions of Cameroon [81]. In this perspective, a number of development infrastructures 


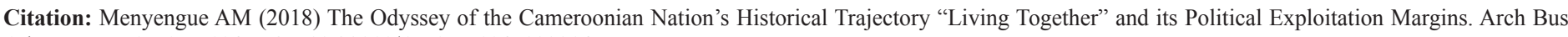
Adm Manag: ABAM-114. DOI: 10.29011/ABAM-114. 100014.

in regions and specific areas were built to facilitate their integration policy. Development as national integration horizon therefore justifies the development projects and their "announcement effects" all over the national territory. In this respect, the region or the locality which do not benefit from a development project often voice against their "marginalization". The memoranda are often published to voice these frustrations. So if unity and national cohesion are the conditions for development, development is the purpose of the nation. The common effort for economic growth and its fruits should be geographically and ethno regionally modulate into development projects to consolidate the "living together". To be eligible for one or more projects of economic development, infrastructure, health, cultural, sporting, social or political is highly important for an ethno-regional group to the extent that, it promotes, finally, its national integration. That was the purpose of the five-year project under President Ahmadou Ahidjo, for example. We can also consider the emergency plan of development settled to boost the social, economic and cultural development of the far north region in the aftermath of the conflict against Boko Haram, etc.

\section{Conclusion}

The analysis of the Cameroonian's nation building process leads to the conclusion that the "best interests of the nation" is the alpha and omega of operational policies and public policy agendas even if it is also subject of continuous political manipulation. The nation is a common pretext to justify political and hegemonic ambitions as well as the constitutional instability which is put into contribution in order to sustain political messianism built around the figures of president Ahmadou Ahidjo and his successor president Paul Biya. The historical process that led to the unitary state in Cameroon was presented as the path for the national project par excellence. Constitutional changes to the adoption of a non limited presidential mandate through the abolition of the post of Prime Minister in 1991, and later the suppression of the constitutional provision which limited the number of presidential mandate are both some of the means used to politicize the nation building process for personal purposes [82]. In this respect "national unity appears to be a "concept directeur"[83] which can be also used as a "catch all argument"

\section{References}

1. Renan E. (1997) Qu'est ce qu'une nation ?, Paris, Editions Mille et une nuits, p. 41

2. Kymlicka W (2001) Multiculturel Citizenship, a liberal theory of minority rights, Paris, La Decouverte : 25.

3. Lavroff D.J. (1972) «Régimes militaires et développement politique en Afrique noire ", La revue française de science politique, 5 : 912-936.

4. Ngadjui N. (1989) La conception camerounaise de la Nation, thèse de Doctorat en Science politique, University of Yaounde II Soa
5. Nguelieutou A (2004) Le peuple dans la vie politique camerounaise postcoloniale, Thèse de Doctorat de science politique, Université de Yaounde II.

6. Braudel F., « Histoire et Sciences sociales : La longue durée », Annales Économies, Sociétés, Civilisations. 13ieme année, $n^{\circ}$ 4, 1958. p. 728.

7. Ricœur P. (1992) «Le retour de l'évènement », Mélanges de l'Ecole française de Rome. Italie et Méditerranée, 41: 29-35.

8. Max Weber the concept of «communalisation» revisit to a social relationship when, and as, the provision of social activity is based - in the particular case, on average or in the pure type - the subjective feeling (traditional or emotional) of the participants belong to the same community [Zusammengehörigkeit]. " Read Mr. Weber Economy and Society Paris Plon $1995: 78$.

9. Collective «change the Cameroon», Cameroon is broke? commented Anthology of ethnic claims, Yaounde, Editions C3 1992.

10. Hirschman 1970 «Exit, voice, and loyalty; responses to decline in firms, organisms and states «, Cambridge, Harvard University Press.

11. Bayart J-F. (1985) L'Etat au Cameroun, Paris, PFNSP : 228.

12. From the speech of closing of the 2 nd congress of the Cameroon National Union September 1983 in Renewal Message, speech and interview of President Paul Biya, year 1, Yaoundé, SOPECAM, 1986, p. 237.

13. Gaillard P., (1994) Ahidjo Ahidjo, patriote ou despote, bâtisseur de l'Etat du Cameroun, Paris, Groupe Jeune Afrique : 111.

14. Akono Evang SP (2010) «L'unité nationale comme concept directeur ", Revue d'Etudes Politiques et Stratégiques, Yaoundé, Université de Yaoundé II-Soa : 132.

15. Ahidjo (1980) Anthologie des discours, Yaoundé, SOPECAM, 1980: 53.

16. Gaillard P., (1994) Ahmadou Ahidjo, patriote ou despote, bâtisseur de l'Etat du Cameroun, Paris, Groupe Jeune Afrique ; Eboua E. (1996), Ahidjo et la logique du pouvoir, Paris, L'Harmattan.

17. Art. 5 (2) of Law No. 96/06 of 18 January 1996 amending the Constitution of 2 June 1972modifiée and supplemented by Law No. 2008/001 of 14 April 2008.

18. Kamto M. (1987) Pouvoi et droit en Afrique noire : essai sur les fondements du constitutionnalisme dans les Etats d'Afrique noire francophone, Paris, LGDJ : 432.

19. Ahidjo (1980) Anthologie des discours, Yaoundé, SOPECAM, 1980: 1228-1241.

20. Ahidjo (1980) Ahidjo (1980) Anthologie des discours, Yaoundé, SOPECAM, 1980: 53, SOPECAM 1228-1241

21. Njoya J (2003) «Liturgies politiques, construction d'un imaginaire unitaire et démocratie passive au Cameroun», Revue d'Etudes Politiques et Stratégiques, $n^{\circ}-1 / 2003$, Yaoundé, Université de Yaoundé II-Soa: 31.

22. Nkoum, Me-Tseny LM (1997) «Dynamic English positioning and political liberalization in Cameroon: the identity identification,» IRIC-GRAP, available at http // www.polis science-politiques- Bordeaux.fr, flight $6: 7$

23. Nkoum, Me-Tseny LM (1997) "Dynamique de positionnement anglophone et libéralisation politique au Cameroun : de l'identité à 
Citation: Menyengue AM (2018) The Odyssey of the Cameroonian Nation's Historical Trajectory "Living Together" and its Political Exploitation Margins. Arch Bus Adm Manag: ABAM-114. DOI: 10.29011/ABAM-114. 100014.

I'identification ", IRIC-GRAP, disponible sur http//www.polis-sciencespolitiques- Bordeaux.fr, vol. 1, nous/article 6, html, 1997, p.7,» IRICGRAP, available at http // www.polis science-politiques- Bordeaux.fr, flight $6: 7$.

24. Bayart (1970) «L'Union nationale Camerounaise» Revue française de science politique, 20. $4: 681-718$

25. Bjarne Melkevik (2000) Réflexion sur la philosophie du droit, Laval, l'Harmattan, Presses de l'Université Laval, 2000 : 139.

26. Sindjoum L (1996) «Identité nationale et révision constitutionnelle du 18 Janvier 1996 : Comment constitutionalise t- on le « nous » au Cameroun dans l'Etat post-unitaire ?» Polis, :3.

27. Njoya J (2003) «Liturgies politiques, construction d'un imaginaire unitaire et démocratie passive au Cameroun», Revue d'Etudes Politiques et Stratégiques, $n^{\circ}-1 / 2003$, Yaoundé, Université de Yaoundé II-Soa : 36.

28. Ahidjo (1980) Ahidjo (1980) Anthologie des discours, Yaoundé, SOPECAM, 1980: 1302.

29. Ngayap PF (1983) Cameroun, Qui gouverne? D'Ahidjo à Biya, l'héritage et l'enjeu, Paris, Le Harmattan.

30. Sindjoun $L$ (1996) «Identité nationale et révision constitutionnelle du 18 Janvier 1996 : Comment constitutionalise t- on le « nous » au Cameroun dans l'Etat post-unitaire ?» Polis, : 10.

31. This balance of power that marked the so-called constitutional mutation helps to understand the relative consistency of the final constitutional text

32. Sindjoun $L$ (1996) "L'imagination constitutionnelle de la nation", in Melone S., Minkoa She A., Sindjoun L., (Dir), La réforme constitutionnelle du 18 janvier 1996 au Cameroun. Aspects juridiques et politiques, Yaoundé, Fondation Friedrich-Ebert, 1996, p. 7777.

33. Bourmaud D (1977) La politique en Afrique, Paris, Montchrestien, 1997; Gicquel J. «Essai sur le presidentialisme négro-africain : l'exemple Camerounais» in Mélanges en l'honneur de Georges Burdeau, LGDJ, Paris, 1977Ahidjo (1980) Anthology speeches, New African edition t.1, Yaounde, SOPECAM 49.

34. Moluh Y (1996) «L'introuvable nature du régime camerounais issu de la Constitution du 18 janvier 1996» GRAP-Cameroon, Friedrich Ebert Foundation in Cameroon : 242-250.

35. Sindjoun L (2002) L'Etat au Cameroun: entre noyau dur et case vide, Paris, Karthala : 305.

36. Biya P (2009) The people call. 1 Yaoundé, SOPECAM 2009.

37. Owona Nguini ME (2007) “ Le gouvernement perpétuel en Afrique centrale : le temps politique présidentialiste entre autoritarisme et parlementarisme en zone CEMAC " Enjeux Geopolitiques en Afrique Centrale : 255-268.

38. Menguele Menyengue AM (2016) L'intrigue de l'alternance présidentielle au Cameroun : entre jeux de simulation, d'exclusion and positionnement politique, Saarbrücken, European Editions Universitaires.

39. Biya P (2011) The people call, Yaounde, SOPECAM : 196

40. Nlep RG (1986) L'administration publique camerounaise : " contribution à l'étude des systèmes africains d'administration publique, Paris, LGDJ 259.
41. Kymlicka W. (2001), Multicultural Citizenship. A liberal theory of minority rights, Paris, La Découverte : 150.

42. Hermet G. Badie B. et al, (1998) Dictionary of political science and political institutions, Paris, Armand Colin.

43. Ngayap PF (1983) Cameroun, Qui gouverne? D’Ahidjo à Biya, I'héritage et l'enjeu, Paris, Le Harmattan.

44. Read the preamble of Law No. 96/06 of 18 January 1996 amending the Constitution of 2 June 1972modifiée and supplemented by Law No. 2008/001 of 14 April 2008.

45. Van Den Walle N (2001) «The impact of multi-party politics in subSaharian Africa» Forum for Development Studies, No. -1 / 33.

46. Read the speech to the nation President Ahmadou Ahidjo, thanks to the reshuffle of June 21, 1961, in A. Ahidjo, speeches 1957-1979 Anthology, New African Publishing 1980. 1; 134.

47. Amado G, Guillet A (1990) Dynamique de la communication de groupe, Paris, Armand Colin.

48. On the theory of «mirror representation» read Achin C., « La représentation miroir» vs parité. Débats parlementaires sur la parité à la lumière de théorie de la représentation politique", Droit et Societé 2001. $47: 237-256$

49. Ngayap PF (1983) Cameroun, Qui gouverne? D'Ahidjo à Biya, l'héritage et l'enjeu, Paris, Le Harmattan : 38.

50. Jürgen Habermas (1998) L'intégration républicaine, Paris, Fayard 225.

51. Njoya J (2005) Unité nationale et mutations politiques : essai sur la régulation symbolique et conservatrice dans le système politique camerounais (1982-2000), Thèse de doctorat d'Etat, Université de Yaounde II-Soa : 182.

52. Arendt Lijphart (1977) Democracy in Plural Societies: A Comparative Exploration. New Haven, Yale University Press.

53. Collective "Changer le Cameroun," le Cameroun éclaté? Anthologie commentée des revendications ethniques, Yaounde, C3 Editions 1993.

54. Collective "Changer le Cameroun,» le Cameroun éclaté? Anthologie commentée des revendications ethniques, Yaounde, C3 Editions 1993.

55. Njoya J (2005) Unité nationale et mutations politiques : essai sur la régulation symbolique et conservatrice dans le système politique camerounais (1982-2000), Thèse de doctorat d'Etat, Université de Yaounde II-Soa :433.

56. Mouiche I (1996) « Mutations sociopolitiques et replis identitaires en Afrique: le cas du Cameroun ", Revue Africaine de science politique, n², vol.1, 1996, pp. 31-56», African Journal of Political Science. 1 $31-56$.

57. Kamto M (1999) Déchéance de la politique, décrépitude morale ou exigence éthique dans le gouvernement des hommes en Afrique, Yaoundé, Edition Mandara.

58. Sindjoun L. (1998) La politique d'affection en Afrique noire, Publication Graps, Boston, Boston University Press

59. Sindjoun L (2002) L'Etat ailleurs : entre noyau dur et case vide, Paris, Karthala, $2002: 312$. 
Citation: Menyengue AM (2018) The Odyssey of the Cameroonian Nation's Historical Trajectory "Living Together" and its Political Exploitation Margins. Arch Bus Adm Manag: ABAM-114. DOI: 10.29011/ABAM-114. 100014.

60. Ngayap P.-F (1999) au Cameroun, les années de braises, Paris, l'harmattan; Alawadi Zelao, "Opposition in Cameroon and responsibility of the electorate," in Rethinking and rebuilding the Cameroonian opposition. Question about the search for meaning and political subjectivity, Eboussi Boulaga F. et al, (Dir), Yaounde, soils Publishing : 356-357.

61. Clausewitz C (2014) the conflict, Paris, Astrea.

62. Akono Evang SP (2010) "L'unité nationale comme concept directeur », Revue d'Etudes Politiques et Stratégiques, Yaoundé, Université de Yaoundé II-Soa : 127-145.

63. G. Simmel, Conflict, Paris, Circe, 1992; L. Coser, The Social functions of Conflict, Paris, PUF, 1982; Mr. Wieviorka, "The paradoxical virtues of the conflict", Humanities, off-series No. 47, Violence DecemberJanuary-February 2004 to $2005: 22-24$.

64. Mr. Edelman (1991 Pièces et règles du jeu Politique, Paris, Seuil : 64.

65. Ngniman Z (1996) Nigeria- Cameroun, la guerre permanente ? Yaoundé édition clé, Essai, 1996 : 94-95.

66. Simmel G. (1995) Le Conflict, Paris, Editions Cirée.

67. Menguele Menyengue AM (2017) «About the conflict as an alternative mode of» communalisation "essay on political behavior in terms of the war against Boko Haram in Cameroon», in Gwoda AA \& Wassouni F. (Dir) Boko Haram in Cameroon: plural dynamic, Brussels, PIE-Peter Lang43-62.

68. E. Elias, Dunning E (1994) Sport and civilization, Paris, Fayard.

69. Defrance J (2011) "IV. The social functions of the sport, "Sociology of Sport. La Découverte 71-80.

70. E. Elias, Dunning E (1994) Sport and civilization, Paris, Fayard63.

71. Clausewitz C (2014) The conflict, Paris, Astrea.

72. P. Biya (2009) quoted by YatieYakam C. The form of exchange and power in football in Cameroon. Contribution to an analysis of social issues of high performance sport in sub-Saharan Africa, PhD in Science and technology of physical activities and sports, University of Strasbourg14.
73. Njoya J (2005) Unité nationale et mutations politiques : essai sur la régulation symbolique et conservatrice dans le système politique camerounais (1982-2000), Thèse de doctorat d'Etat, Université de Yaounde II-Soa : 370 .

74. Cameroon- Tribune, No. -9509-5710 of Monday, January 4, $2010: 2$.

75. Ntonfo A (1994) Football et politique au Cameroun, Yaoundé, Le Crac, $1994: 209$

76. P. Biya (2011) The people call, Yaounde, SOPECAM.

77. Speech on the occasion of the inauguration of the Bamenda-Bafoussam highway of 15 February 1977 in A. Ahidjo, Anthology speeches, Yaounde, Presence Africaine, t. 2, 1980 : 1959.

78. Speech on the occasion of the inauguration of the Bamenda-Bafoussam highway of 15 February 1977 in A. Ahidjo (1980) Anthologie des discours, Yaoundé, SOPECAM, 1980:1959.

79. Ela Ela E, Mbog lbock MR (2017) "Governing by instruments in complex situations: the economy of the emergency plan in the fight against Boko Haram," in Gwoda AA \& Wassouni F. (Dir) Boko Haramau Cameroon: Dynamic plural, Brussels, PIE-Peter Lang261-284.

80. Dessouane $P$, Glass $P(1986)$ “ Du développement autocentré au national-libéralisme », in Le réveil du Cameroun, $1986: 111-119$.

81. Ela Ela E, Mbog lbock MR (2017) «Governing by instruments in complex situations: the economy of the emergency plan in the fight against Boko Haram», in Gwoda AA \& Wassouni F. (Dir) Boko Haramau Cameroon: Dynamic plural, Brussels, PIE-Peter Lang261-284.

82. Akono Evang SP (2010) "L'unité nationale comme concept directeur", Revue d'Etudes Politiques et Stratégiques, Yaoundé, Université de Yaoundé II-Soa, 2010 : 132 